\title{
sciendo
}

\section{THE IMPORTANCE OF NUTRITION IN ALLEVIATING HIGH STOCKING DENSITY STRESS IN POULTRY - A REVIEW}

\author{
Esra Tuğçe Gül, Alpönder Yildiz, Osman Olgun• \\ Department of Animal Science, Faculty of Agriculture, Selcuk University, 42130 Konya, Turkey \\ •Corresponding author: oolgun@selcuk.edu.tr
}

\begin{abstract}
In recent decades, the number of birds reared per unit area has dramatically spiked to increase profitability in egg and meat production. However, nowadays, the increase in sensitivity to animal welfare and consumer demands brings along with it a raised interest in stocking density. Stocking density is defined either as the number of animals or body weight per unit area or as the area per animal. High stocking density, which is a stress factor, can be defined as an increase in the number of animals per unit area or a decrease in the area per animal. Stress caused by high stocking density negatively affects the bird's physiology and performance as well as the quality of the product obtained. The ideal stocking density should be 9 laying hens, 35 kilograms for broilers, and 45 quails per square metre. Otherwise, one will observe stress indicators in birds reared in more than the recommended stocking density per unit area and, consequently, a decrease in bird growth, egg production, feed efficiency, and egg or meat quality. Apart from increasing the concentrations of amino acids such as lysine, methionine, tryptophan and arginine, minerals such as selenium and chromium, and vitamins such as $\mathrm{C}$ and $\mathrm{E}$ in the diet, the addition of additives such as probiotics, humates, phytophenol compounds, and propolis is also effective in reducing or eliminating these negative effects caused by high stocking density. As a result, regulations in the nutrition of animals are effective in reducing/preventing such negative effects, thus improving animal welfare and ensuring the maintenance of optimum yield.
\end{abstract}

Key words: stocking density, stress, nutrition, laying hen, broiler

Today, the demand for food of animal origin for adequate and balanced nutrition is constantly increasing. In parallel with this, the issue of producing animal proteins in the cheapest way and in the shortest time takes an important place. Poultry production is placed near the top in this respect. To increase profitability in the poultry industry, which is continuously developing in terms of both the amount of product and productivity in the world, one should aim to rear more birds per unit area as well as optimise the genetic structure and feeding and raising conditions.

Stocking density, which is defined as the number of animals per unit area or body weight (Estevez, 2007), is a very important issue in poultry production as it is closely related to performance and animal welfare problems (Zhang et al., 2013). With the rapid development of the poultry industry, many breeders aim to obtain more products per unit area with the highest possible stocking density to achieve more economic benefits. However, since high stocking density causes stress in poultry and hence negatively affects the welfare, health, and performance of the birds, it has become a remarkable issue in recent years (Yin et al., 2017; Sapsuha et al., 2021).

A characteristic feature of living organisms is their ability to try to maintain physiological and biochemical homeostasis. Pawlak and Kontecka (1995) defined all factors that disrupt this stability (homeostasis) as stressors and the response to them as stress. According to Sugiharto et al. (2017), 'stress' is a term that describes the organism's responses to abnormal circumstances that potentially disrupt homeostasis or normal physiological balance. Therefore, stress represents the organism's response (a biological response) to stimuli that disrupt normal physiological balance or homeostasis. In industrial poultry production, the birds are exposed to a series of stress factors. Stress, depending on the factor and its density, can create positive effects by initiating high adaptation and increasing the general immunity of the organism. All that being said, the extent and consequences of metabolic events are determined by the type, prevalence, and duration of stress, and exposure to very immense and long-term stress factors can cause impaired immunity, decreased production performance, the increased incidence of pathological symptoms, and even death (Fitko et al., 1992; Pijarska et al., 2006).

With regard to animal welfare, high stocking density should be avoided, and a sufficient range should be left for the birds to exhibit natural behaviour. However, feeding strategies are important in preventing the loss of yield and product quality as a result of the stress caused by high stocking density if more birds are housed in the unit area than recommended. For this purpose, it was reported that 
increasing amino acid (Srinongkote et al., 2004; Toghyani et al., 2016), vitamin (Desoky and Kamel, 2018; Wang et al., 2021), and mineral (Sohail et al., 2001; Jahanian and Mirfendereski, 2015) concentrations in the diet and the supplementation of additives (Ma et al., 2020; Wu et al., 2020 a) are effective in reducing/preventing high stocking density stress. In light of the above information, this review aims to briefly provide information about the ideal stocking density and the negative effects of high stocking density stress as well as to evaluate the prevention of these adverse effects on poultry by nutrition.

\section{High stocking density stress and optimum stock- ing density}

Increasing the number of birds reared per unit area is a factor that reduces housing and equipment costs. More animals being housed in a unit area can cause the birds' skeletal and muscle development and performance to be adversely affected because of the reduction of feeders and drinkers per bird and the limitation of movement (Cengiz et al., 2015). Along with the decrease in body weight, feed intake, and feed efficiency (López-López et al., 2021; Guardia et al., 2011; Zuowei et al., 2011; Tong et al., 2012; Sun et al., 2013; Cengiz et al., 2015) in broilers with increasing stocking density, footpad dermatitis, foot swelling, hyperkeratosis, and leg weakness increase (Sørensen et al., 2000; Dozier et al., 2005; Lay et al., 2011), small intestinal villi structures deteriorate, and nutrient absorption diminishes (Shakeri et al., 2014; Li et al., 2017). However, high stocking density decreases lymphocytes and increases heterophiles among the immune components (thus an augmented heterophile:lymphocyte ratio) (Astaneh et al., 2018), reducing the immune response (Mustafa et al., 2010; Turkyilmaz, 2008). In addition, high stocking density can increase the incidence of footpad and hock problems as a result of such density negatively affecting litter quality (Kang et al., 2016). As well, more than the recommended stocking density can cause adverse environmental conditions such as heat stress and a decrease in airflow, in which case individual deaths can be observed (Feddes et al., 2002).

The optimum values suggested in some studies in the literature on the stocking density considerably affecting the health and welfare of poultry are as follows. The European Union Council Directive 1999/74/EC determined the maximum stocking density for laying hens as 9 hens/ $\mathrm{m}^{2}\left(750 \mathrm{~cm}^{2} /\right.$ hen, minimum) after 1 January 2012 . The United Egg Producers (UEP, 2008) on the other hand, suggested the optimum stocking density for white and brown strains as 432 and $555 \mathrm{~cm}^{2} /$ hen, respectively. Other studies noted that the optimum stocking density for laying hens is $375 \mathrm{~cm}^{2} /$ hen until 45 weeks of age and 450 $\mathrm{cm}^{2} /$ hen after 45 weeks of age (Rios et al., 2009), 733 $\mathrm{cm}^{2} /$ hen (Benyi et al., 2006) or 7-9 hens $/ \mathrm{m}^{2}$ (Zimmerman et al., 2006) in semi-arid regions, and 1,000-2,000 $\mathrm{cm}^{2} /$ hen (Saki et al., 2012) or 5 hens $/ \mathrm{m}^{2}$ (Kang et al., 2016) depending on the financial condition of the enterprise. EU 2007/43/EC stated that the stocking density for broil- ers should be $33 \mathrm{~kg} / \mathrm{m}^{2}$, which could be $39 \mathrm{~kg} / \mathrm{m}^{2}$ under more proper housing conditions, and $42 \mathrm{~kg} / \mathrm{m}^{2}$ if herd management and viability can be guaranteed (European Union, 2007). Nasr et al. (2021) reported that the optimum stocking density in broiler chicks is $18 \mathrm{birds} / \mathrm{m}^{2}$ in terms of both performance and animal welfare. Other values for the optimum stocking density for broilers include 17 birds $/ \mathrm{m}^{2}$ (Gholami et al., 2020), 14-18 birds $/ \mathrm{m}^{2}$ (Kryeziu et al., 2018), 14.3 birds $/ \mathrm{m}^{2}$ (Feddes et al., 2002) in arid regions, and 30 chicks $/ \mathrm{m}^{2}$ depending on age (Qaid et al., 2016). Some researchers reported that the stocking density could be increased up to $50 \mathrm{~kg} / \mathrm{m}^{2}$ in coops with litter (Shanawany, 1988; Grashorn and Kutritz, 1991; Thaxton et al., 2006). For laying quails, the stocking density was indicated as 45 quails $/ \mathrm{m}^{2}$ (Ratriyanto et al., 2020). The research results explained above demonstrate that the optimum stocking density differs at different ages and under different environments, or production systems.

The stress mechanism consists of three phases: alarm, adaptation, and exhaustion. In these phases, glucocorticoids (Ravindran et al., 2006) as well as blood glucose (Puvadolpirod and Thaxton, 2000) and cholesterol (Dozier et al., 2006) levels increase, an imbalance in the heterophil:lymphocyte is observed because of a decrease in lymphocytes, and some changes such as an increase in pulsation, blood pressure and respiratory rate are experienced. Adrenal insufficiency seen in the exhaustion phase causes pathological changes, and ultimately death occurs (Öziş Altınçekiç and Koyuncu, 2012). To reduce stress in poultry, methods such as the enrichment and improvement of environmental conditions and breeding practices are used. Along with the management methods applied in previous years, interest in diet manipulation has increased in recent years (Taşkın et al., 2015). For this reason, this review focuses on this issue.

Prevention of stocking density stress by nutrition Importance of protein and amino acids in diet

Protein synthesised in poultry plays an important role in the structure of products such as meat and eggs as well as in the formation of feathers that protect the skin against wounds and infections (Lopez-Coello, 2003), improving immunity (Swain and Johri, 2000; Attia et al., 2005). The effects of some essential amino acids, which are important in the synthesis of proteins, in animals exposed to stress are summarised below.

Methionine is the first limiting amino acid because the vegetable protein sources used in the diet are insufficient in terms of this amino acid, and it is necessary for feather growth and protein synthesis. Foot and hock wounds are related to each other, and these are caused by high stocking density and high litter moisture (Mayne, 2005; Dozier et al., 2005). Toghyani et al. (2016) reported that foot and hock injuries increased in broilers reared at high stocking densities (16 or 18 chicks $/ \mathrm{m}^{2}$ ) and that these problems were reduced with the use of high levels of sulphurous amino acids (120\% of need) in the diet. Miao et al. (2021) stated that the negative effects 
of high stocking density ( $\left.20 \mathrm{birds} / \mathrm{m}^{2}\right)$ on the immunity of broilers could be prevented by adding methionine to the diet $(0.40 \%-0.45 \%)$, but this positive effect was not observed in the performance, and while a $0.40 \%$ dietary methionine level was sufficient in optimum density (14 birds $/ \mathrm{m}^{2}$ ), this should be $0.45 \%$ in high stocking density $\left(20\right.$ birds $\left./ \mathrm{m}^{2}\right)$.

Lysine (Chang et al., 1993) and arginine (McCracken and Stewart, 2001; Obled et al., 2002) are two amino acids that can reduce the adverse effects of stress. However, the effects of stress factors on the mentioned amino acids differ because of the antagonism between them (Han and Baker, 1993; Brake et al., 1998). The addition of lysine and arginine double the recommended level to the diets of broilers reared at high stocking density (12 broilers/ $\mathrm{m}^{2}$ ) increases body weight and lymphocytes, but this positive effect is not observed in carcass yield and neutrophil and monocyte counts (Srinongkote et al., 2004).

Tryptophan is an essential amino acid in monogastric animals since it cannot be synthesised. Rech et al. (2010) stated that the negative effects of high stocking density on laying hens housed at densities of 563, 450, or $375 \mathrm{~cm}^{2} /$ hen were not affected by different levels of tryptophan $(0.175 \%, 0.195 \%, 0.392 \%$, or $0.591 \%)$ in the diet. In another study, $0.18 \%$ tryptophan was effective in improving feed efficiency, and $0.27 \%$ tryptophan was effective in increasing plasma glucose levels in broilers under high stocking density (11 and 15.4 chicks $/ \mathrm{m}^{2}$ ) stress (Wang et al., 2014).

It can be said that individual essential amino acid needs, which can vary according to yield aspect and period, are higher when the birds are exposed to high stress. Therefore, the positive effect of increasing the amounts of methionine, lysine, and other essential amino acids in the diet can be attributed to this.

\section{Importance of energy level of diet}

Sarı̈zkan et al. (2009) stated that the stocking density ( 285.7 and $500 \mathrm{~cm}^{2} /$ hen) did not affect performance in laying hens, but for hens fed with diets containing high energy $(2,850 \mathrm{kcal} / \mathrm{kg})$, feed intake decreased, and feed efficiency improved compared with hens fed with diets containing low energy $(2,650 \mathrm{kcal} / \mathrm{kg})$.

\section{Importance of vitamins}

It was reported that the supplementation of 25-hydroxycholicalciferol to the diet increased body weight gain (Bello et al., 2013), improved the meat quality of broilers, and diminished tibial dysplasia (Ledwaba and Roberson 2003; Świątkiewicz et al., 2006), while hatchability, immunity (Saunders-Blades and Korver, 2015), and eggshell quality (Keshavarz, 2003) in chickens improved. In laying hens aged 45 weeks, reared at low (506 $\mathrm{cm}^{2} /$ hen) and high $\left(338 \mathrm{~cm}^{2} /\right.$ hen) stocking densities, egg production, egg weight, feed intake, eggshell quality, tibia (Wang et al., 2020) and duodenal crypt depth, shortchain fatty acids (propionic and butyric acid) in the cecum, and serum levels of superoxide dismutase, catalase, and malondialdehyde (Wang et al., 2021) were adversely affected from high stocking density, but the addition of $69 \mu \mathrm{g} / \mathrm{kg}$ of vitamin $\mathrm{D}_{3}$ to the diet was effective in eliminating these negative effects (Wang et al., 2020, 2021).

Vitamin $\mathrm{E}$ is considered an essential nutrient for the growth and health of all animal species (McDowell, 2012). One of the most important properties of vitamin $\mathrm{E}$, which is very important in terms of nutritional myopathy, prostaglandin biosynthesis and immunity, is that it is a powerful antioxidant. Vitamin E protects cells and tissues from oxidative damage caused by free radicals (Lin et al., 1996). Adebiyi (2011) examined the effects of supplementing $0,50,100$, or $150 \mathrm{mg} / \mathrm{kg}$ of vitamin $\mathrm{E}$ (alpha-tocopherol acetate) to the diets of broilers at different stocking densities (10 and 20 chicks $/ \mathrm{m}^{2}$ ) and announced that the broilers can be raised at 20 chicks $/ \mathrm{m}^{2}$ by adding $100 \mathrm{mg} / \mathrm{kg}$ of vitamin E to the diet. Desoky and Kamel (2018), on the other hand, showed that the body weight gain and feed efficiency of Japanese quail chicks reared at different stocking densities ( 80 and 100 chicks $/ \mathrm{m}^{2}$ ) were adversely affected by the high density $\left(100\right.$ chicks $\left./ \mathrm{m}^{2}\right)$, but the mentioned parameters as well as mineral accumulation improved with the addition of $200 \mathrm{mg} / \mathrm{kg}$ of vitamin $\mathrm{E}$ to the diet.

Vitamin $\mathrm{C}$ is a vitamin that is effective in stress circumstances (Naseem et al., 2005). Vitamin C concentration in the plasma, which plays a role in the synthesis of white blood cells alongside participating in mineral and amino acid metabolism, decreases under stress conditions, and its synthesised amount cannot satisfy this need (Khan et al., 2012; Attia et al., 2018). It was found that the decreased plasma vitamin $\mathrm{C}$ level in laying hens exposed to high stocking density ( 7 hens $\left./ 0.18 \mathrm{~m}^{2}\right)$ stress, ascended again with the addition of ascorbic acid to the diet, that plasma corticosterone concentration and malondialdehyde levels of plasma and yolk decreased again, and that feed efficiency improved considerably (Mirfendereski and Jahanian, 2015). Similarly, vitamin C can alleviate the harmful effects of stress by reducing the synthesis and secretion of corticosteroids (McDowell, 2000). Ratriyanto et al. (2020) stated that the supplementation of $250 \mathrm{mg} / \mathrm{kg}$ vitamin $\mathrm{C}$ to the diets of quails reared at 40 , 45 , and 50 quails $/ \mathrm{m}^{2}$ densities prevented the decrease in egg production of quails housed at high stocking density $\left(50\right.$ quails $\left./ \mathrm{m}^{2}\right)$. The positive effect of vitamin C supplementation in stress circumstances is due to the insufficient amount of its synthesised form under these conditions; this situation causes protein catabolism and low protein biosynthesis given the increase of cytotoxic free radicals that damage the cell and cell membranes (İpek et al., 2007).

\section{Importance of minerals}

Articles on the use of minerals in eliminating the negative effects of high stocking density on poultry are quite few compared with those on vitamins and additives. These studies are summarised below. Sohail et al. (2001) indicated that egg production and feed intake linearly declined with the increase in stocking density 
(300, 400 or $600 \mathrm{~cm}^{2} /$ hen); egg production subsequently advanced with the increasing available phosphorus level (from $0.15 \%$ to $0.40 \%$ ) in the diet, and this could be due to the decrease in feed and phosphorus intake caused by stocking density.

Copper is an essential element in the use of iron in the synthesis of haemoglobin and as a cofactor for enzymes such as cytochrome A, ascorbic acid oxidase, and superoxide dismutase (Wedekind et al., 1992; İpek et al., 2003). Olgun and Aygun (2017) reported that the stocking density $\left(500,417\right.$, and $357 \mathrm{~cm}^{2} /$ hen $)$ did not affect the perfor- mance of aged laying hens, but interestingly, it advanced eggshell thickness, and the heterophile:lymphocyte ratio changed significantly with the addition of copper in the group with the highest stocking density. The supplementation of selenium at levels of 0.15 and $0.30 \mathrm{mg} / \mathrm{kg}$ to the diets of Japanese quail chicks reared at high stocking density $\left(100\right.$ chicks $\left./ \mathrm{m}^{2}\right)$ was effective in eliminating the negative effects of stocking density stress on body weight and feed efficiency and also regulated calcium and phosphorus metabolism levels (Desoky and Kamel, 2018).

Table 1. The effect of some nutrients/additives on the prevention of high stocking density stress

\begin{tabular}{|c|c|c|c|c|c|}
\hline Birds & Age & Stocking density & Nutrient/additive & Results & References \\
\hline \multicolumn{6}{|c|}{ Nutrients } \\
\hline Broilers & $22 \mathrm{~d}$ & 20 chicks $/ \mathrm{m}^{2}$ & Methionine, $0.35,0.40,0.45$ or $0.50 \%$ & Oxidative stress decreased & Miao et al. (2021) \\
\hline Broilers & $18 \mathrm{~d}$ & 12 chicks $/ \mathrm{m}^{2}$ & $\begin{array}{l}\text { Lysine and arginine, twice as much of } \\
\text { need }\end{array}$ & $\begin{array}{l}\text { Animal welfare and feed } \\
\text { efficiency improved }\end{array}$ & $\begin{array}{l}\text { Srinongkote et al. } \\
(2004)\end{array}$ \\
\hline Broilers & $25 \mathrm{~d}$ & 15.4 chicks $/ \mathrm{m}^{2}$ & Tryptophan, $0.27 \%$ & $\begin{array}{l}\text { Animal welfare and feed } \\
\text { efficiency improved }\end{array}$ & Wang et al. (2014) \\
\hline Laying hens & $45 \mathrm{wk}$ & $338 \mathrm{~cm}^{2} /$ hen & 25-hydroxycholecalciferol, $69 \mu \mathrm{g} / \mathrm{kg}$ & $\begin{array}{l}\text { Performance and bone qual- } \\
\text { ity traits improved }\end{array}$ & Wang et al. (2020) \\
\hline Growing quails & $8 \mathrm{~d}$ & 100 quails $/ \mathrm{m}^{2}$ & $\begin{array}{l}\text { Vitamin E, } 200 \mathrm{mg} / \mathrm{kg} \\
\text { Selenium, } 0.30 \mathrm{mg} / \mathrm{kg} \\
\text { Vitamin E } 50+\text { selenium } 0.15 \mathrm{mg} / \mathrm{kg}\end{array}$ & $\begin{array}{l}\text { Body weight gain and feed } \\
\text { efficiency increased }\end{array}$ & $\begin{array}{l}\text { Desoky and Kamel } \\
\text { (2018) }\end{array}$ \\
\hline Laying hens & $26 \mathrm{wk}$ & $\begin{array}{l}7 \text { hens/cage }(40 \times 45 \\
\mathrm{cm})\end{array}$ & $\begin{array}{l}\text { Organic chromium, } 500 \text { and } 1000 \mu \mathrm{g} / \mathrm{kg} \\
\text { Vitamin C } 500 \mathrm{mg} / \mathrm{kg}\end{array}$ & $\begin{array}{l}\text { Chromium improved } \\
\text { performance and antioxi- } \\
\text { dant capacity, plasma MDA } \\
\text { level decreased. Vitamin C } \\
\text { diminished MDA of plasma } \\
\text { and yolk }\end{array}$ & $\begin{array}{l}\text { Jahanian and } \\
\text { Mirfendereski (2015) }\end{array}$ \\
\hline \multicolumn{6}{|c|}{ Additives } \\
\hline Laying hens & $54 \mathrm{wk}$ & $360 \mathrm{~cm}^{2} /$ hen & Probiotic, 0.15 and $0.30 \%$ & $\begin{array}{l}\text { Performance and metabolic } \\
\text { profile improved }\end{array}$ & Yörük et al. (2004) \\
\hline Layer quails & $10 \mathrm{wk}$ & 84 and $126 \mathrm{~cm}^{2} /$ quail & Humate and prebiotic, $0.2 \%$ & $\begin{array}{l}\text { Egg production, egg weight } \\
\text { and feed efficiency advanced } \\
\text { when both were added }\end{array}$ & Yörük et al. (2008) \\
\hline Broilers & $22 \mathrm{~d}$ & 18 chicks $/ \mathrm{m}^{2}$ & Alpha-lipoic acid, $300 \mathrm{mg} / \mathrm{kg}$ & $\begin{array}{l}\text { Performance improved, } \\
\text { physiological response to } \\
\text { stress increased }\end{array}$ & Ma et al. (2020) \\
\hline Broilers & $21 \mathrm{~d}$ & $18 \mathrm{chicks} / \mathrm{m}^{2}$ & $\begin{array}{l}\text { Nicotinamide, } 50 \text { and } 100 \mathrm{mg} / \mathrm{kg} \\
\text { Sodium butyrate, } 500 \text { and } 1000 \mathrm{mg} / \mathrm{kg}\end{array}$ & Meat quality increased & Wu et al. $(2020 \mathrm{~b})$ \\
\hline Laying hens & $50 \mathrm{wk}$ & $580 \mathrm{~cm}^{2} /$ hen & Tarragon, $1.2,6.0$ or $12 \mathrm{mg} / \mathrm{kg}$ & $\begin{array}{l}\text { Performance, immune sys- } \\
\text { tem and intestinal microflora } \\
\text { were positively affected }\end{array}$ & Kaya et al. (2021) \\
\hline Growing quails & $8 \mathrm{~d}$ & $80 \mathrm{~cm}^{2} /$ quail & $\begin{array}{l}\text { Propolis ethanol extract, } 0.5,1.0 \\
\text { or } 1.5 \mathrm{mg} / \mathrm{kg}\end{array}$ & $\begin{array}{l}\text { Body weight, feed intake and } \\
\text { feed efficiency improved }\end{array}$ & Arslan et al. (2014) \\
\hline Growing quails & $7 \mathrm{~d}$ & $90 \mathrm{~cm}^{2} /$ quail & $\begin{array}{l}\text { Thyme volatile oil, } 200,400 \\
\text { or } 600 \mathrm{mg} / \mathrm{kg}\end{array}$ & $\begin{array}{l}\text { Intestinal microflora, perfor- } \\
\text { mance and carcass advanced }\end{array}$ & Önel and Aksu (2020) \\
\hline Broilers & $15 \mathrm{~d}$ & 10 and 16 birds $/ \mathrm{m}^{2}$ & $\begin{array}{l}\text { Encapsulated Cosmos caudatus leaf } \\
\text { extract, } 0.5 \text { and } 1.0 \mathrm{~g} / \mathrm{kg}\end{array}$ & Body weight increased & $\begin{array}{l}\text { Agusetyaningsih et al. } \\
\text { (2021) }\end{array}$ \\
\hline Broilers & $15 \mathrm{~d}$ & $16 \operatorname{birds} / \mathrm{m}^{2}$ & Nutmeg flesh extract, $0.5,1.0,1.5 \mathrm{ml} / \mathrm{kg}$ & $\begin{array}{l}\text { Improved performance } \\
\text { parameters }\end{array}$ & Sapsuha et al. (2021) \\
\hline Broilers & $1 \mathrm{~d}$ & $\begin{array}{l}25,30,35 \text {, and } 40 \\
\mathrm{~kg} / \mathrm{m}^{2}\end{array}$ & $\begin{array}{l}\text { Lemongrass essential oil and tea tree } \\
\text { essential oil, } 300 \mathrm{mg} / \mathrm{kg}\end{array}$ & $\begin{array}{l}\text { Better results were obtained } \\
\text { from tea tree essential oil } \\
\text { than lemongrass essential oil }\end{array}$ & Ghanima et al. (2021) \\
\hline
\end{tabular}


Chromium is essential for carbohydrate, fat, and protein metabolism (McCarty, 1991; Anderson, 1997). Stress and illness increase the urinary excretion of chromium (Anderson et al., 1988), and augmented chromium excretion can increase the need for this element and can create significant deficiency in stress circumstances (Starich and Blincoe, 1983). It was found that the addition of chromium $(0,500$, or $1,000 \mu \mathrm{g} / \mathrm{kg})$ to the diets of laying hens exposed to stocking density stress ( 5 and 7 hens $/ 0.18 \mathrm{~m}^{2}$ ) was effective in eliminating the adverse effects of high stocking density on egg production, egg mass, and feed efficiency, and the serum vitamin $\mathrm{C}$ level and antioxidant capacity in the birds increased (Jahanian and Mirfendereski, 2015). The same researchers (Mirfendereski and Jahanian, 2015) clarified that the plasma insulin and glucose levels became concentrated as the stocking density increased and descended with the addition of chromium to the diet; also, high stocking density considerably increased the plasma corticosterone level, but the chromium and stocking density interaction did not significantly affect plasma corticosterone.

Boron is very important for various metabolic and physiological systems, although its biochemical mechanism in humans and animals has not been fully determined (Hunt, 2003). On the other hand, Özdemir et al. (2016) - by adding $0,25,50$, or $75 \mathrm{mg} / \mathrm{kg}$ of boron to the diets of quails with stocking densities of 70, 65, and $50 \mathrm{~cm}^{2} /$ quail - reported no interaction between the stocking density and boron when the performance parameters were examined cumulatively; however, the positive effects of boron addition increased as the stocking density decreased on the thymus weight and the size of the bursa of Fabricius.

\section{Importance of additives}

First of all, additives, which do not have harmful effects on human or animal health, are added to the diet and positively affect the performance and product quality of the animals, and these are widely used in poultry nutrition today. Additives can also have beneficial effects in reducing the stress caused by high stocking density (Table 1).

\section{Probiotics and prebiotics}

Stress factors negatively affect intestinal microflora balance and cause decreases in product quantity and quality (Lan et al., 2004). Probiotics and prebiotics are additives that increase the number of lactic acid bacteria in the intestinal microflora, suppress the increase of intestinal pathogens, and strengthen immunity (Jadamus et al., 2001; Ehrmann et al., 2002; Ghareeb et al., 2008). Given these positive effects on the intestinal microflora, probiotics and prebiotics can be added to the diets of birds as stress reducers. It was explained that the supplementation of $0.15 \%$ and $0.30 \%$ probiotics to the diets of hens housed in $540-360 \mathrm{~cm}^{2} /$ bird stocking densities improves feed intake and feed efficiency, which are negatively affected by stocking density (Hayirli et al., 2005). Also, the addition of 2 and $1 \mathrm{~g} / \mathrm{kg}$ of prebiotics to the starter and finisher diets, respectively, did not considerably affect performance, lymphoid organ weight, and blood glucose, cholesterol, and corticosterone concentrations as well as the heterophile:lymphocyte ratio in broilers raised at high stocking density (16 birds $/ \mathrm{m}^{2}$ ) (Houshmand et al., 2012). In contrast, Yörük et al. (2008) reported that the increased stocking density $\left(84,126\right.$, and $252 \mathrm{~cm}^{2} /$ quail) of quails affected their performance and blood parameters negatively, but these negative effects were reduced with the supplementation of $0.2 \%$ prebiotics (dextran oligosaccharide) to the diet.

\section{Humates}

Humates are composed of humic acids and salts originated from humus formed by some substances such as carbohydrates, amino acids, and phenols, which are the decomposition products of organic substances in the soil. Furthermore, humic acids are composed of humic, fulvic, and ulmic acids as well as salts and minerals from humus. It was clarified that humate compounds prevent the growth of pathogenic microorganisms by providing optimum $\mathrm{pH}$ formation in the digestive tract, increasing the bioavailability of calcium and various trace minerals (İslam et al., 2005); humic and fulvic acids also play a role in the detoxification of pathogenic bacterial toxins by chelating with heavy metals such as lead and mercury (Klocking, 1980). Çetin et al. (2011) found that the lymphocyte count descended in hens housed at two different densities (287 and $500 \mathrm{~cm}^{2} /$ bird) given the increase in stocking density, and when $0.15 \%$ humate was added to the diet, the lymphocyte count became concentrated. According to research conducted with quails reared at different stocking densities $\left(252,126\right.$, or $84 \mathrm{~cm}^{2} /$ quail), as the stocking density increased, the body weight changed, and egg production, egg weight, feed efficiency, and blood traits were adversely affected; this negative effect of stocking density was reduced by adding $0.2 \%$ humate to the diet (Yörük et al., 2008).

\section{Herbal products}

Zhang et al. (2013) reported that the supplementation of $100 \mathrm{mg} / \mathrm{kg}$ of Forsythia suspensa, $100 \mathrm{mg} / \mathrm{kg}$ of berberine, and $100 \mathrm{mg} / \mathrm{kg}$ of Forsythia suspensa +100 $\mathrm{mg} / \mathrm{kg}$ of berberine to the diets of $6\left(28 \mathrm{~kg} / \mathrm{m}^{2}\right)$ or $10(46$ $\mathrm{kg} / \mathrm{m}^{2}$ ) broilers raised in $0.54 \mathrm{~m}^{2}$ positively affected the birds' performance by increasing immunity, reducing oxidative stress, and improving digestive system microflora at high stocking density. Another study reported that the administration of 0.5 and $1.0 \mathrm{~g} / \mathrm{kg}$ of encapsulated Cosmos caudatus leaf extract to broiler diets had a positive effect on body weight at high stocking density (10 and 16 birds $/ \mathrm{m}^{2}$, respectively) (Agusetyaningsih et al., 2021). By adding $0,1.2,6$, or $12 \mathrm{~g} / \mathrm{kg}$ of tarragon (Artemisia dracunculus L.) to the diets of laying hens housed at different densities ( 5 or 7 hens/cage), serum corticosterone, total immunoglobulin and total oxidant concentrations, malondialdehyde levels of the serum, liver, and egg, and 
intestinal E. coli decreased; on the contrary, serum IgG levels increased in hens at high stocking density $\left(7\right.$ hens $\left./ \mathrm{m}^{2}\right)$ (Kaya et al., 2021). The addition of 200, 400, and $600 \mathrm{mg} /$ $\mathrm{kg}$ of thyme essential oil to the diets of quails reared at high stocking density $\left(90 \mathrm{~cm}^{2} /\right.$ quail $)$ eliminated the negative effects of stocking density on performance, carcass, and small intestine microflora; it would also be beneficial to supplement a high level $(600 \mathrm{mg} / \mathrm{kg})$ of thyme essential oil to the diet so as to remove the negative effects of high stocking density (Önel and Aksu, 2020). In addition, Sapsuha et al. (2021) stated that the supplementation of $0.5,1.0$, and $1.5 \mathrm{ml} / \mathrm{kg}$ of nutmeg flesh extract to the diets of broiler chicks raised at high stocking density (16 birds/ $\mathrm{m}^{2}$ ) improved performance parameters without affecting internal organ weight and carcass yield.

\section{Apitherapy}

Bee products are widely used in traditional medicine given their antioxidant, antimicrobial and anti-inflammatory properties (Aygun et al., 2012). It is reported that bee pollen, which contains almost all of the major and minor elements, is rich in protein, carbohydrates and lipids (Villanueva et al., 2002), has a protective effect against free radicals (Aliyazıcıoğlu et al., 2005) and contains polyphenol compounds with significant antioxidant potential (Campos et al., 1997; Schmidt, 1997). Some researchers declared that the supplementation of $1 \mathrm{~g} / \mathrm{kg}$ of bee pollen (Seven et al., 2011) or 0.51 .0 or $1.5 \mathrm{~g} / \mathrm{kg}$ of propolis ether extract (Arslan et al., 2014) to quail chicks diets raised at different densities ( 80 and $160 \mathrm{~cm}^{2} /$ chick) eliminated the negative effects of high stocking density on performance. In another study by the same researchers, the administration of royal jelly at 250 and $500 \mathrm{mg} / \mathrm{kg}$ of body weight to quails was effective in eliminating the negative effects of high stocking on body weight, body weight gain, and feed intake (Seven et al., 2014). This positive effect of bee products is because they contain compounds with antioxidant activity such as flavonoids (Arslan et al., 2014).

\section{Other additives}

Ghanima et al. (2021), in their resarch conducted by adding $300 \mathrm{mg} / \mathrm{kg}$ of tea tree essential oil and $300 \mathrm{mg} / \mathrm{kg}$ of lemon grass essential oil to the diets of broilers raised at $25,30,35$, and $40 \mathrm{~kg} / \mathrm{m}^{2}$ stocking densities, stated that the supplementation of tea tree essential oil did positively affect performance, meat traits, and cellular immunity, and better results were obtained from tea tree essential oil than lemon grass essential oil at high settlement density. Wu et al. (2020 a) reported that the supplementation of $50 \mathrm{mg} / \mathrm{kg}$ of nicotinamide and $500 \mathrm{mg} / \mathrm{kg}$ of sodium butyrate to the diets of 21-day-old broilers raised at 14 and 18 birds $/ \mathrm{m}^{2}$ stocking densities did not affect feed intake, body weight, body weight gain, and feed efficiency; cooking loss was reduced, and $\mathrm{pH}$ and lactate dehydrogenase enzyme activity was optimised in birds with high stocking density with the addition of nicotinamide and sodium butyrate to the diet. Sarıözkan et al. (2009) stated that the addition of L-carnitine at the level of $200 \mathrm{mg} /$ $\mathrm{kg}$ to the diets of hens reared at 285.7 and $500 \mathrm{~cm}^{2} /$ hen stocking densities did not have an economic effect. Bone quality was adversely affected, with physiological and oxidative stress indicators augmented in broilers raised at high stocking density (18 birds $\left./ \mathrm{m}^{2}\right)$, but performance and physiological stress indicators improved with the addition of alpha-lipoic acid $(300 \mathrm{mg} / \mathrm{kg}$ ) to the diet (Ma et al., 2020). In another study, the addition of nicotinamide (50 and $100 \mathrm{mg} / \mathrm{kg}$ ) and sodium butyrate ( 500 and $1,000 \mathrm{mg} / \mathrm{kg}$ ) to the diets of broilers raised at high stocking density $\left(18.6 \mathrm{birds} / \mathrm{m}^{2}\right)$ improved the meat quality (Wu et al., 2020 b). Jeong et al. (2020) reported that the supplementation of $100 \mathrm{mg} / \mathrm{kg}$ of gamma-amino butyric acid to broiler diets housed at high stocking density $\left(15\right.$ birds $\left./ \mathrm{m}^{2}\right)$ could not prevent poor performance, but it had positive effects on corticosterone and the heterophile:lymphocyte ratio.

\section{Conclusion}

Increasing the stocking density in poultry production is a method applied to obtain more products per unit area - in other words, to increase profitability. However, this technique could adversely affect product quantity and quality. It has been observed that increasing the level of antioxidant nutrients in the diet and adding additives are effective in reducing the stress caused by high stocking density to prevent the decrease in product quantity and quality.

\section{Disclosure of potential conflicts of interest}

No potential conflict of interest was reported by the author(s).

\section{References}

Adebiyi O.A. (2011). Tocopherol supplementation on stocking density of broiler: effect on performance characteristics and serum enzymes. Trop. Subtrop. Agroeco., 14: 623-628.

Agusetyaningsih I., WidiastutiE., Wahyuni H.I., Yudiarti T., Murwani R., Sartono T.A., Sugiharto S. (2021). Effect of encapsulated Cosmos caudatus leaf extract on the physiological conditions, immune competency, and antioxidative status of broilers at high stocking density. Ann. Anim. Sci. (in press).

Aliyazıcıŏ̆lu Y., Değer O., Ovalı E., Barlak Y., Hosver I., Tekelioğlu Y., Karahan S.C. (2005). Effects of Turkish pollen and propolis extracts on respiratory burst for k-562 cell lines. Int. Immunopharmacol., 5: 1652-1657.

Anderson R.A. (1997). Chromium as an essential nutrient for humans. Reg. Toxicol. Pharmacol., 26: 35-41.

Anderson R.A., Bryden N.A., Polansky M.M., Deuster P.A. (1988). Exercise effects on chromium excretion of trained and untrained men consuming a constant diet. J. Appl. Physiol., 64: 249-252.

Arslan A.S., Seven P.T., Yilmaz S., Seven I. (2014). The effects of propolis on performance, carcass and antioxidant status characteristics in quails reared under different stocking density. Eur. Poult. Sci., 78: 1-11.

Astaneh I.Y., Chamani M., Mousavi S.N., Sadeghi A.A., Afshar M.A. (2018). Effects of stocking density on performance and immunity in Ross 308 broiler chickens. Kafkas Univ. Vet. Fak. Derg., 24: 483-489.

Attia Y.A., Hassan R.A., Shehatta M.H., El-Hady S.A. (2005). Growth, carcass quality and serum constitients of slow growing chicks as 
affected by betain addition to diets containing 2 different levels of methionine. Int. J. Poultry Sci., 4: 856-865.

Attia Y.A., Abd El-Hamid A.E., Abdallah A.A., Berikaa M.A., El-Gandy M.F., Sahin K., Abou-Shehema B.M. (2018). Effect of betaine, vitamin $\mathrm{C}$ and vitamin $\mathrm{E}$ on egg quality, hatchability, and markers of liver and renal functions in dual-purpose breeding hens exposed to chronic heat stress. Eur. Poultry Sci., 82.

Aygun A., Sert D., Copur G. (2012) Effects of propolis on eggshell microbial activity, hatchability, and chick performance in Japanese quail (Coturnix coturnix japonica) eggs. Poultry Sci., 91: $1018-1025$.

Bello A., Zhai W., Gerard P.D., Peebles E.D. (2013). Effects of the commercial in ovo injection of 25-hydroxycholecalciferol on the hatchability and hatching chick quality of broilers. Poultry Sci., 92: 2551-2559.

Benyi K., Norris D., Tsatsinyane P.M. (2006). Effects of stocking density and group size on the performance of white and brown Hyline layers in semi-arid conditions. Trop. Anim. Health Prod., 38 619-624.

Brake J., Balnave D., Dibner J.J. (1998). Optimum dietary arginine:lysine ratio for broiler chickens is altered during heat stress in association with changes in intestinal uptake and dietary sodium chloride. Brit. Poultry Sci., 39: 639-647.

Campos M.G., Cunha A., Markham K.R. (1997). Bee-pollen: Composition, properties, and applications, Mizrahi A., Lensky Y. (eds). Bee Products (Properties, Applications, and Apitherapy), Plenum Press, New York, USA, pp: 93-100.

Cengiz O., Köksal B.H., Tatlı O., Sevim O., Ahsan U., Under A.G., Ulutas P.A., Beyaz D., Buyukyoruk S., Yakan A., Önol A.G. (2015). Effect of dietary probiotic and high stocking density on the performance, carcass yield, gut microflora, and stress indicators of broilers. Poultry Sci., 94: 2395-2403.

Chang Y.F., Wing Y., Cauley R.K., Gao X.M. (1993). Chronic lysine develops anti-pentylenetetrazol tolerance and reduces synaptic GABAergic sensitivity. Eur. J. Pharmacol., 233: 209-217.

Çetin E., Güçlü B.K., Çetin N. (2011). Effect of dietary humate and organic acid supplementation on social stress induced by high stocking density in laying hens. J. Anim. Vet. Adv., 10: 2402-2407.

Desoky A.A., Kamel N.N. (2018). Dietary supplementation of vitamin $\mathrm{E}$ and selenium alleviate the negative effects of high stocking density in growing Japanese quail. Egypt. J. Nutr. Feeds, 21: 783-791.

Dozier W.A., Thaxton J.P., Branton S.L., Morgan G.W., Miles D.M., Roush W.B., Lott B.D., Vizzier-Thaxton Y. (2005). Stocking density effects on growth performance and processing yields of heavy broilers. Poultry Sci., 84: 1332-1338.

DozierW.A., Thaxton J.P., Purswell J.L., Olanrewaju H.A., Branton S.L., Roush W.B. (2006). Stocking density effects on male broilers grown to 1.8 kilograms of body weight. Poultry Sci., 85: 344-351.

Ehrmann M.A., Kurzak P., Bauer J., Vogel R.F. (2002). Characterization of lactobacilli towards their use as probiotic adjuncts in poultry. J. Appl. Microbiol., 92: 966-975.

Estevez I. (2007). Density allowances for broilers: Where to set the limits? Poultry Sci., 8: 1265-1272.

European Communities (1999). Council Directive 1999/74/EC., Official Journal of the European Communities, L203/53.

European Union (2007). Council Directive 2007/43/EC, Laying down minimum rules for the protection of chickens kept for meat production, Official Journal of the European Union, 182: 1928.

Feddes J.J., Emmanuel E.J., Zuidhoft M.J. (2002). Broiler performance, body weight variance, feed and water intake, and carcass quality at different stocking densities. Poultry Sci., 81: 774-779.

Fitko R., Jakubowski K., Roszko E., Potrzuska I., Zieliński H. (1992). Narastanie oporności kurcząt do przewlekle powtarzanego stresu (in Polish). Med. Weter., 48: 29-31.

Ghanima M.M.A., Swelum A.A., Shukry M., Ibrahim S.A., Abd ElHack M.E., Khafaga A.F., Alhimaidi A.R., Ammari A.A., El-Tarabily K.A., Younis M.E. (2021). Impacts of tea tree or lemongrass essential oils supplementation on growth, immunity, carcass traits, and blood biochemical parameters of broilers reared under different stocking densities. Poultry Sci., 101443.

Ghareeb K., Awad W.A., Nitsch S., Abdel-Raheem S., Bohm J. (2008).
Effects of transportation on stress and fear responses of growing broilers supplemented with prebiotic or probiotic. Int. J. Poultry Sci., 7: 678-685.

Gholami M., Chamani M., Seidavi A., Sadeghi A.A., Aminafschar M. (2020). Effects of stocking density and environmental conditions on performance, immunity, carcase characteristics, blood constitutes, and economical parameters of Cobb 500 strain broiler chickens. Ital. J. Anim. Sci., 19: 524-535.

Grashorn M., Kutritz B. (1991). Der Einfluss der Besatzdichte auf die Leistung moderner Broilerherkünfte. Arch. Geflugelkd., 55: 84-90.

Guardia S., Konsak B., Combes S., Levenez F., Cauquil L., Guillot J.F., Moreau-Vauzelle C., Lessire M., Juin H., Gabriel I. (2011). Effects of stocking density on the growth performance and digestive microbiota of broiler chickens. Poultry Sci., 90: 1878-1889.

Han Y., Baker D.H. (1993). Effect of sex, heat stress, body weight and generic strain on the dietary lysine requirement of broiler chicks. Poultry Sci., 72: 701-708.

Hayirli A., Esenbuğa N., Macit M., Yörük M.A., Yıldız A., Karaca H. (2005). Nutrition practice to alleviate the adverse effects of stress on laying performance, metabolic profile and egg quality in peak producing hens: II. The probiotic supplementation. Asian-Australas. J. Anim. Sci., 18: 1752-1760.

Houshmand M., Azhar K., Zulkifli I., Bejo M.H., Kamyab A. (2012). Effects of prebiotic, protein level, and stocking density on performance, immunity, and stress indicators of broilers. Poultry Sci., 91: 393-401.

Hunt C.D. (2003). Dietary boron: An overview of the evidence for its role in immune function. J. Trace Elem. Experimental Med., 16: 291-306.

İpek H., Yertürk M., Avc1 M. (2003). The effect of different amounts of zinc and copper supplementation on egg production and some blood parameters in laying period quail diets. YYÜ. Vet. Fak. Derg., 14: 65-68.

İpek A., Canbolat O., Karabulut A. (2007). The effect of vitamin E and vitamin $\mathrm{C}$ on the performance of Japanese quails (Coturnix coturnix japonica) reared under heat stress during growth and egg production period. Asian-Australas. J. Anim. Sci., 20: 252-256.

İslam K.M.S., Schuhmacher A., Gropp J.M. (2005). Humic acid substances in animal agriculture. Pak. J. Nutr., 4: 126-134.

Jadamus A., Vahjen W., Simon O. (2001). Growth behaviour of a sporeforming probiotic strain in the gastrointestinal tract of broiler chicken and piglets. Arch. Anim. Nutr., 54: 1-17.

Jahanian R., Mirfendereski E. (2015). Effect of high stocking density on performance, egg quality, and plasma and yolk antioxidant capacity in laying hens supplemented with organic chromium and vitamin C. Livest. Sci., 177: 117-124.

Jeong S.B., Kim Y.B., Lee J.W., Kim D.H., Moon B.H., Chang H.H., Choi Y.H., Lee K.W. (2020). Role of dietary gamma-amino butyric acid in broiler chickens raised under high stocking density. Anim. Nutr., 6: 293-304.

Kang H.K., Park S.B., Kim S.H., Kim C.H. (2016). Effects of stock density on the laying performance, blood parameter, corticosterone, litter quality, gas emission and bone mineral density of laying hens in floor pens. Poultry Sci., 95: 2764-2770.

Kaya H., Karaalp M., Kaynar Ö., Tekçe E., Aksakal A., Bayram B. (2021). Tarragon (Artemisia dracunculus L.) could alleviate negative effects of stocking density in laying hens. Braz. J. Poultry Sci., 23: 1-12.

Keshavarz K. (2003). A comparison between cholecalciferol and 25-OH-cholecalciferol on performance and eggshell quality of hens fed different levels of calcium and phosphorus. Poultry Sci., 82: 1415-1422.

Khan R.U., Naz S., Nikousefat Z., Selvaggi M., Laudadio V., Tufarelli V. (2012). Effect of ascorbic acid in heat-stressed poultry. World's Poultry Sci. J., 68: 477-490.

Klocking R. (1980). Giftung und Endgiftung von Schwermetallendurch Huminsäuren, Arch. Exper. Vet. Med., 34: 389-393.

Kryeziu A.J., Kamberi M., Muji S., Mestani N., Berisha S. (2018). Carcass traits of broilers as affected by different stocking density and sex. Bulg. J. Agri. Sci., 24: 1097-1103.

Lan P.T.N., Sakamoto M., Benno Y. (2004). Effects of two probiotic 
Lactobacillus strains on jejunal and cecal microbiota of broiler chicken under acute heat stress condition as revealed by molecular analysis of 16S rRNA genes. Microbiol. Immun., 48: 917-929.

Lay Jr D.C., Fulton R.M., Hester P.Y., Karcher D.M., Kjaer J.B., Mench J.A., Porter R.E. (2011). Hen welfare in different housing systems. Poultry Sci., 90: 278-294.

Ledwaba M.F., Roberson K.D. (2003). Effectiveness of twenty-fivehydroxycholecalciferol in the prevention of tibial dyschondroplasia in Ross cockerels depends on dietary calcium level. Poultry Sci., 82: 1769-1777.

Li J., Miao Z., Tian W., Yang Y., Wang J., Yang Y. (2017). Effects of different rearing systems on growth, small intestinal morphology and selected indices of fermentation status in broilers. Anim. Sci. J., 88: 900-908.

Lin Y.L., Juan I.M., Chen Y.L., Liang Y.C., Lin J.K. (1996). Composition of polyphenols in fresh tea leaves and associations of their oxygen-radical-absorbing capacity with antiproliferative actions in fibroblast cells. J. Agri. Food Chem., 44: 1387-1394.

Lopez-Coello C. (2003). Potential causes of broiler feathering problems. Feathering manual. St Louis, MO: Novus International, $1-46$.

López-López P., Sarmiento-Franco L.A., Santos-Ricalde R. (2021) Effect of stocking density on performance, infection by Eimeria spp., intestinal lesions and foot pad injuries in broilers with outdoor access under tropical conditions. Brit. Poultry Sci., (in press).

Ma H., Xu B., Li W., Wei F., Kim W.K., Chen C., Sun Q., Fu C., Wang G., Li S. (2020). Effects of alpha-lipoic acid on the behavior, serum indicators, and bone quality of broilers under stocking density stress. Poultry Sci., 99: 4653-4661.

Mayne R.K. (2005). A review of the etiology and possible causative factors of footpad dermatitis in growing turkeys and broilers. World's Poultry Sci. J., 61: 256-267.

McCarty M.F. (1991). The case for supplemental chromium and a survey of clinical studies with chromium picolinate. J. Appl. Nutr., 43: 59-66.

McCracken K.J., Stewart R.A. (2001). Importance of amino-acid and electrolyte balance in experimental diets used to determine the apparent metabolizable energy (AME) value of wheat. Brit. Poultry Sci., 42: 64-69.

McDowell L.R. (2012). Vitamins in animal nutrition - Comparative aspects to human nutrition. Academic Press, London, pp. 10-54.

McDowell L.R. (2000). Vitamins in animal and human nutrition. Iowa State University Press.

Miao Z.Q., Dong Y.Y., Qin X., Yuan J.M., Han M.M., Zhang K.K., Shi S.R., Song X.Y., Zang J.Z., Li J.H. (2021). Dietary supplementation of methionine mitigates oxidative stress in broilers under high stocking density. Poultry Sci., 100: 101231.

Mirfendereski E., Jahanian R. (2015). Effects of dietary organic chromium and vitamin $\mathrm{C}$ supplementation on performance, immune responses, blood metabolites, and stress status of laying hens subjected to high stocking density. Poultry Sci., 94: 281-288.

Mustafa M.Y., Muneer M.A., Anjum A.A., Ahamd M. (2010). Influence of stocking density on immune response of broilers against Newcastle disease virus. Pak. J. Life Soc. Sci., 8: 7-10.

Naseem S., Younus M., Anwar B., Ghafoor A., Aslam A., Akhter S. (2005). Effect of ascorbic acid and acetyl salicylic acid supplementation on performance of broiler chicks exposed to heat stress. Int. J. Poultry Sci., 4: 900-904.

Nasr M.A., Alkhedaide A.Q., Ramadan A.A., Abd-El Salam E.H., Hussein M.A. (2021). Potential impact of stocking density on growth, carcass traits, indicators of biochemical and oxidative stress and meat quality of different broiler breeds. Poultry Sci., 101442.

Obled C., Papet I., Breuillé D. (2002). Metabolic bases of amino acid requirements in acute diseases. Curr. Opin. Clin. Nutr. Metabolic Care, 5: 189-197.

Olgun O., Aygun A. (2017). Effect of copper supplementation on performance, eggshell quality and heterophil:lymphocyte ratio in aged laying hens housed at different stocking densities. Anim. Nutr. Feed Technol., 17: 25-33.

Önel S.E., Aksu T. (2020). Can thyme (Thymbra spicata L. var. spicata) volatile oil alleviate the detrimental effects of high stocking densities in Japanese quail? Turk. J. Vet. Anim. Sci., 44: 10241031.

Özdemir G., İnci H., Söğüt B., Şengül T., Yüksel H., Şimşek H., Özdemir A. (2016). Effects of dietary boron supplementation on performance and some haematological and antioxidant parameters in Japanese quail exposed to high stocking density. Eur. Poulry Sci., 80: 1-15.

Öziş Altınçekiç Ş., Koyuncu M. (2012). Farm animals and stress. J. Anim. Prod., 53: 27-37.

Pawlak M., Kontecka H. (1995). Stres u zwierząt (in Polish). Pol. Drob., 4: 8-10.

Pijarska I., Czech A., Malec H., Tyczyna L. (2006). Wpływ transportu drogowego piskląt na wskaźniki biochemiczne krwi oraz wyniki produkcyjne brojlerów (in Polish). Med. Weter., 62: 408-410.

Puvadolpirod S., Thaxton J.P. (2000). Model of physiological stress in chickens: 1. Response parameters. Poultry Sci., 79: 363-369.

Qaid M., Albatshan H., Shafey T., Hussein E., Abudabos A.M. (2016). Effect of stocking density on the performance and immunity of 1-to 14-d-old broiler chicks. Braz. J. Poultry Sci., 18: 683-692.

Ratriyanto A., Firmanda F., Purwanti H., Murjoko M. (2020). Nutrient digestibility, performance, and egg quality traits of quails raised in different stocking densities and ascorbic acid supplementation in a hot, tropical environment. Turk. J. Vet. Anim. Sci., 44: 350-357.

Ravindran V., Thomas D.V., Thomas D.G., Morel P.C.H. (2006). Performance and welfare of broilers as affected by stocking density and zinc bacitracin supplementation. Anim. Sci. J., 77: 110-116.

Rech O.A., Pinheiro J.W., Fonseca N.A.N., da Silva C.A., Oba A. (2010). Effect of genetic strain, cage space and dietetic tryptophan level on the laying hens performance. Semin. Cienc. Agrar., 31: 1051-1058.

Rios R.L., Bertechini A.G., Carvalho J.C.C., Castro S.F., Costa V.A. (2009). Effect of cage density on the performance of 25 -to 84-week-old laying hens. Braz. J. Poultry Sci., 11: 257-262.

Saki A.A., Zamani P., Rahmati M., Mahmoudi H. (2012). The effect of cage density on laying hen performance, egg quality, and excreta minerals. J. Appl. Poult. Res., 21: 467-475.

Sapsuha Y., Suprijatna E., Kismiati S., Sugiharto S. (2021). The effect of nutmeg flesh (Myristica fragrans Houtt) extract on growth performance, internal organ and carcass of broiler chickens raised at high stocking density. Livest. Res. Rural Dev., 33: (in press).

Sarıözkan S., Güçlü B.K., İşcan K.M. (2009). Technical and economic evaluation of stocking density, dietary energy level and carnitine supplementation on laying hens. Ankara Üni. Vet. Fak. Der., 56: 283-288.

Saunders-Blades J.L., Korver D.R. (2015). Effect of hen age and maternal vitamin $\mathrm{D}$ source on performance, hatchability, bone mineral density, and progeny in vitro early innate immune function. Poultry Sci., 94: 1233-1246.

Schmidt J.O. (1997). Chemical composition and application, Mizrahi A., Lensky Y. (eds). Bee Products (Properties, Applications and Apitherapy), New York, Plenum Press, pp: 15-26.

Seven İ, Seven P.T., Aslan A.S., Yildiz N. (2011). The effects of dietary bee pollen on performance and some blood parameters in Japanese quails (Coturnix coturnix japonica) breeding under different stocking densities. J. Fac.Vet. Med. Univ. Erciyes, 8: 173-180.

Seven I., Şimşek Ü.G., Gökçe Z., Seven P.T., Arslan A., Yılmaz Ö. (2014). The effects of royal jelly on performance and fatty acid profiles of different tissues in quail (Coturnix coturnix japonica) reared under high stocking density. Turk. J. Vet. Anim. Sci., 38: 271-277.

Shakeri M., Zulkifli I., Soleimani A.F., O'Reilly E.L., Eckersall P.D., Anna A.A., Abdullah F. F.J. (2014). Response to dietary supplementation of L-glutamine and L-glutamate in broiler chickens reared at different stocking densities under hot, humid tropical conditions. Poultry Sci., 93: 2700-2708.

Shanawany M.M. (1988). Broiler performance under high stocking densities. Brit. Poultry Sci. 29: 43-52.

Sohail S.S., Bryant M.M., Rao S.K., Roland D.A. (2001). Influence of cage density and prior dietary phosphorus level on phosphorus requirement of commercial leghorns. Poultry Sci., 80: 769-775.

Sørensen P., Su G., Kestin S.C. (2000). Effects of age and stocking 
density on leg weakness in broiler chickens. Poultry Sci., 79: 864-870.

Srinongkote S., Smriga M., Toride Y. (2004). Diet supplied with Llysine and L-arginine during chronic stress of high stock density normalizes growth of broilers. Anim. Sci. J., 75: 339-343.

Starich G.H., Blincoe C. (1983). Dietary chromium-forms and availabilities. Sci. Tot. Envir., 28: 443-454.

Sugiharto S., Yudiarti T., Isroli I., Widiastuti E., Kusumanti E. (2017) Dietary supplementation of probiotics in poultry exposed to heat stress - a review. Ann. Anim. Sci., 17: 591-604.

Sun Z.W., Yan L., Zhao J.P., Lin H., Guo Y.M. (2013). Increasing dietary vitamin D3 improves the walking ability and welfare status of broiler chickens reared at high stocking densities. Poultry Sci., 92: 3071-3079.

Swain B.K., Johri T.S. (2000). Effect of supplemental methionine, choline and their combinations on the performance and immune response of broilers. Brit. Poultry Sci., 41: 83-88.

Świątkiewicz S., Koreleski J., Kopowski J. (2006). Effect of phytase and 25-hydroxycholecalciferol on the performance and bone quality in broiler chickens. Med. Weter., 62: 81-84.

Taşkın A., Şahin A., Camcı Ö., Erener G. (2015). New approaches to anti-stress practices in poultry. Turk. J. Agri. Food Sci. Technol., 3: 571-576.

Thaxton J.P., Dozier W.A., Branton S.L., Morgan G.W., Miles D.W., Roush W.B., Lott B.D., Vizzier-Thaxton Y. (2006). Stocking density and physiological adaptive responses of broilers. Poultry Sci., 85: 819-824.

Toghyani M., Heidari S., Emadinia A. (2016). Effect of stocking density and dietary sulfur amino acids on welfare indices of broiler chicks. J. Adv. Agri. Technol., 3: 124-127.

Tong H.B., Lu J., Zou J.M., Wang Q., Shi S.R. (2012). Effects of stocking density on growth performance, carcass yield, and immune status of a local chicken breed. Poultry Sci., 91: 667-673.

Turkyilmaz M.K. (2008). The effect of stocking density on stress reaction in broiler chickens during summer. Turk. J. Vet. Anim. Sci., 32: $31-36$.

United Egg Producers (UEP) (2008). United Egg Producers Animal Husbandry Guidelines for US Egg Laying Flocks. Alpharetta, GA, United Egg Producers.

Villanueva M.O., Marquina A.D., Serrano R.B., Abellán G.B. (2002). The importance of bee-collected pollen in the diet: a study of its composition. Int. J. Food Sci. Nutr., 53: 217-224.

Wang B., Min Z., Yuan J., Zhang B., Guo Y. (2014). Effects of dietary tryptophan and stocking density on the performance, meat quality, and metabolic status of broilers. J. Anim. Sci. Biotechnol., 5: 44.

Wang J., Qiu L., Gong H., Celi P., Yan L., Ding X., Wu C. (2020). Effect of dietary 25-hydroxycholecalciferol supplementation and high stocking density on performance, egg quality, and tibia quality in laying hens. Poultry Sci., 99: 2608-2615.

Wang J., Zhang C., Zhang T., Yan L., Qiu L., Yin H., Ding X., Bai S., Zeng Q., Mao X., Zhang K., Wu C., Xuan Y., Shan Z. (2021). Dietary 25-hydroxy vitamin D improves intestinal health and microbiota of laying hens under high stocking density. Poultry Sci., 100: 101132 .

Wedekind K., Hortin A., Baker D. (1992). Methodology for assessing zinc bioavailability: efficacy estimates for zinc-methionine, zinc sulfate, and zinc oxide. J. Anim. Sci., 70: 178-187.

Wu Y., Wang Y., Yin D., Mahmood T., Yuan J. (2020 a). Transcriptome analysis reveals a molecular understanding of nicotinamide and butyrate sodium on meat quality of broilers under high stocking density. BMC Genom., 21: 1-21.

Wu Y., Wang Y., Wu W., Yin D., Sun X., Guo X., Chen J., Mahmood T., Yan L., Yuan J. (2020 b). Effects of nicotinamide and sodium butyrate on meat quality and muscle ubiquitination degradation genes in broilers reared at a high stocking density. Poultry Sci., 99: 1462-1470.

Yin L.Y., Wang Z.Y., Yang H.M., Xu L., Zhang J., Xing H. (2017). Effects of stocking density on growth performance, feather growth, intestinal development, and serum parameters of geese. Poultry Sci., 96: 3163-3168.

Yörük M.A., Gül M., Hayirli A., Macit M. (2004). The effects of supplementation of humate and probiotic on egg production and quality parameters during the late laying period in hens. Poultry Sci., 83: 84-88.

Yörük M.A., Laçin E., Hayırlı A., Yıldız A. (2008). The effects of humate and prebiotic supplementation on laying performance, egg quality and blood parameters of Japanese quails reared in different cage densities. Yüz. Y1l Üni. Vet. Fak. Der., 19: 15-22.

Zhang H.Y., Piao X.S., Zhang Q., Li P., Yi J.Q., Liu J.D., Li Q.Y., Wang G.Q. (2013). The effects of Forsythia suspensa extract and berberine on growth performance, immunity, antioxidant activities, and intestinal microbiota in broilers under high stocking density. Poultry Sci., 92: 1981-1988.

Zimmerman P.H., Lindberg A.C., Pope S.J., Glen E., Bolhuis J.E., Nicol C.J. (2006). The effect of stocking density, flock size and modified management on laying hen behaviour and welfare in a non-cage system. Appl. Anim. Behav. Sci., 101: 111-124.

Zuowei S., Yan L., Yuan L., Jiao H., Song Z., GuoY., Lin H. (2011). Stocking density affects the growth performance of broilers in a sex-dependent fashion. Poultry Sci., 90: 1406-1415.

Received: 25 VIII 2021

Accepted: 11 X 2021 